1 Axelson O, Davis DL, Forestiere F, Schneidermann M, Wagener D. Lung cancer not attributable to smoking. In: Davis DL, Hoel DG, eds. Trends in cancer mortality in industrial colntries. New York: New York Academy of Sciences, $1990 \cdot 165-78$

2 Carstensen JM, Axelson $\mathrm{O}$. Changes in non-smoking related lung cancer with special reference to mortality trends in Swedish women. In: Davis DI. Hoc DG, eds. Trends in cancer mortality in indistrial countries. New York: New York Academy of Sciences, 1990:159-64

3 National Research Council. Health risks of radon and other internally deposited alpha-emitters: BEIR IV. Washington, DC: National Academy Press, 198

4 National Research Council. Environmental tobacio smoke: measuring exposurs and assessing health effects. Washington, DC: National Academy Press, 1986.

National Research Council. Abestiform fibers: nonoccupational health risks. Washington, DC: National Academy Press, 1984.

6 Rosenstock L, Cullen MR. Clinical occupational medicine. Philadelphia: Saunders, 1986.

7 Holst PA, Kromhout D, Brand R. For debate: pet birds as an independent risk factor for lung cancer. $B M 7$ 1988;297:1319-21.

8 Reed CE, Sosman A, Barbee RA. Pigeon breeders' lung. FAMA 1965;193: $261-5$

9 Fink JN. Sosman AJ, Barboriak JJ, Schlueter DP, Holmes RA. Pigeon breeders' disease: a clinical study of hypersentivity pneumonitis. Ann Intern Med 1968;68:1205-19.

10 Bourke SJ, Carter R, Anderson K, Boyd J, King S, Douglas B, Boyd G. Obstructive airways disease in non-smoking subjects with pigeon fanciers' lung. Clin Exp Allergy 1989;19:629-32.

11 Balasubramaniam SK, O'Connel EJ, Yunginger JW, McDugall JC, Sachs MI Hypersensitivity pneumonitis due to dove antigens in an adolescen Clin Pediatr (Phila) 1987;26:174-6.

12 Grammer LC, Roberts M, Lerner C, Patterson R. Clinical and serologic follow-up of four children and five adults with bird-fanciers' lung. F Allerg Clin Immunol 1990:85:655-60.

13 Ostergaard JR. Reversible pulmonary arterial hypertension in a 6-year-old girl with extrinsic allergic alveolitis. Acta Paediatr Scand 1989;78:145-8.

14 Schlueter DP, Fink N, Sosman AJ. Pulmonary function in pigeon breeders' disease: hypersensitivity pneumonitis. Ann Intem Med 1969;70:457-70.

15 Allen KH, Williams GV, Woolcock AJ. Bird breeders' hypersensitivity pneumonitis: progress studies of lung function after cessation of exposure to the provoking antigen. Am Rev Respir Dis 1976;114:555-66.

16 Hagmar L, Schuetz A, Sjoeholm A. Over-shift decrease in lung function in poultry slaughterhouse workers. Am f Ind Med 1990;17:77-8.

17 Schmidt CDW, Jensen RL, Christensen LT, Crapo RO, Davis JJ. Longitudinal pulmonary function changes in pigeon breeders. Chest 1988;93:359-63

18 Keller RH, Swartz S, Schlueter DP, Bar-Sela S, Fink JN. Immunoregulation in hypersensitivity pneumonitis: phenotypic and functional studies of bronchoalveolar lavage lymphocytes. Am Rev, Respir Dis 1984;130: $766-71$

19 Smith JH, Neill PJ, Dillard EA III, Box ED. Pathology of experimental Sarcoscystis falcatula infections of canaries (Serinus canarius) and pigeons (Columba livia) f Parasitol 1990;76:59-68.

20 Bourke SJ, Banham SW, McKillop JH, Boyd G. Clearance of $99 \mathrm{~m}$ Tc-DTPA in pigeon fanciers hypersensitivity pneumonitis. Am Rev Respir Dis 1990;142:1168-7

21 Bundesminister für Jugend, Familie und Gesundheit Internationale Klassifikation der Krankheiten, Verletzungen und Todesursachen (ICD). Cologne: Kohlhammer, 1988.

22 Statistics and Epidemiology Research Corporation and Cytel Software Corporation. EGRET. Seattle, Washington: SERC, 1991:1-116.

23 Fehr R, Funke U, Kollmeier H, Krasemann EO, Weißker J. Berufsspezifische Krebsrisiken, untersucht anhand des Hamburger Krebsregisters. Hamburger Krebsdokumentation 1978 und 1979. Hamburg: Statistik des Hamburgischen Staates, 1983:137

24 Menck HR, Henderson BE. Occupational differences in rates of lung cancer. 7 Occup Med 1976;18:797-801.

25 Milne KL, Sandler DP, Everson RB, Brown SM. Lung cancer and occupation in Alameda County. A death certificate case-control study. Am 7 Ind Med 1983;4:565-75.

26 Pukkala E, Teppo L, Hakulinen T, Rimpelä M. Occupation and smoking as risk determinants of lung cancer. Int $\mathcal{F}$ Epidemiol 1983;12:290-6.

27 Statistisches Bundesamt. Gesundheitswesen. Fachserie 12. Reihe 4 Todesursachen 1988. Stuttgart: Metzler-Poeschel, 1989.

28 Schlesselman JJ. Case-control studies: design, conduct, analysis. New York: Oxford University Press, 1982

29 Walter S. The estimation and interpretation of attributable risk in health research. Biometrics 1976;32:829-49.

30 Wegener HH, Staib F. Tödliche Cryptococcose eines Vogelliebhabers--Ein kasuistischer Beitrag zur Pathologie, Diagnostik und Epidemiologie der Cryptococcose. Zentralblatt Bakteriologie und Hygiene 1983;256:231-8.

31 Staib F, Seibold M, Antweiler E, Fröhlich B, Heißenhuber M, Voigt R, et al. Cryptococcus neoformans bei Patienten einer Berliner Lungenklinik--Ein Beitrag zur Diagnostik und Bekämpfung der Cr. neoformans-Mykose. Praxis und Klinik der Pneumonologie 1986;40:86-93.

32 Staib F. Kryptokokkose bei AIDS aus mykologisch diagnostischer und -epidemiologischer Sicht. AIDS-Forschung 1987;2:363-82.

33 Staib F. Sampling and isolation of Cryptococcus neoformans from indoor air with the aid of the Reuter Centrifugal Sampler (RCS) and Guizotia abysinica creatinine agar. A contribution to the mycologicalabyssinica creatinine agar. A contribution to the mycologicalepidemiological control of $\mathrm{Cr}$ neoformans in the fecal

34 Staib F, Seibold M, Heißenhuber M. Indoor air mycology-aspergillosis, mucormycosis and cryptococcosis caused by fungal spores from indoor air In: Indoor air '87. Vol 1. Berlin: Institute for Water, Soil and Air Hygiene, 1987:694-8.

35 Staib F, Heißenhuber M. Cryptococcus neoformans in bird droppings: hygienic-epidemiological challenge. AIDS-Forschung 1989; 4: 649-55.

36 Staib F, Bethäuser G. Zum Nachweis von Cryptococcus neoformans im Staub von einem Taubenschlag. Mykosen 1968;11:619-24.

37 James JM, Brouet JC, Orvoenfrija E, Capron F, Brechot J, Danon F, et al. Waldenström's macroglobulinaemia in a bird breeder: a case history with pulmonary involvement and antibody activity of the monocional IgM to canary's droppings. Clin Exp Immunol 1987;68:397-401.

(Accepted 1 fune 1992)

\title{
Avian exposure and bronchogenic carcinoma
}

\section{Austen J S Gardiner, Barbara A Forey, Peter N Lee}

\section{Abstract}

Objective-To investigate the association between bird keeping and risk of lung cancer.

Design-Case-control study asking detailed questions on exposure to domestic birds and other pets, smoking, and various demographic and potentially confounding variables.

Setting-District general hospital; current admissions interviewed in hospital or recent admissions interviewed at home.

Patients-143 patients with lung cancer, 143 controls with heart disease, and 143 controls with orthopaedic conditions individually matched for age, sex, date of admission, and current or past admission.

Main outcome measures-Odds ratios for lung cancer in relation to various aspects of bird keeping, after adjustment for smoking and other relevant confounding variables.

Results-Risk of lung cancer was not significantly associated with household exposure to pet birds at any time or at various specific periods in life, or to keeping large numbers of birds. For specific types of birds no association was seen for living in households with budgerigars or canaries but risk was significantly associated with keeping pigeons (odds ratio 3.53, $95 \%$ confidence interval 1.56 to 7.98 ). This remained significant after regression analysis to account for confounding variables $(3.9,1.2$ to 12.62$)$ in both sexes and all age groups.
Conclusion-Bird keeping may confer some risk of lung cancer but the relation is not as strong as previously reported.

\section{Introduction}

In 1988 Holst et al described results of studies suggesting a strong relation between bird keeping and risk of lung cancer. ${ }^{12}$ An early study in his general practice in the Netherlands found that newly diagnosed malignant tumours in patients aged 30 or more were more common in those who had kept pet birds five to 14 years before diagnosis than in those who had not. Of 12 lung tumours seen, seven were in bird keepers; the expected number was $3.2(p<0 \cdot 05)$. After a small study showing a clear relation between the concentration of suspended particles of $3 \mu \mathrm{g}$ diameter or more and presence of birds in the home, Holst conducted a case-control study in four hospitals in the Hague studying 49 patients with lung cancer and 98 age and sex matched controls from general practice. After adjustment for confounding variables, bird keepers were found to have a 6.7 times increased risk of lung cancer $(95 \%$ confidence interval $2 \cdot 2$ to 20$)$. The increase was similar for keepers of all types of birds and all histological types of lung cancer.

The Netherlands has a high rate of lung cancer and bird keeping, and Holst estimated that had no one in the Hague kept birds the total incidence of lung cancer would have been almost three times lower. He recom- 
mended further, larger, epidemiological studies be undertaken. We describe results of a hospital based case-control study conducted in Lanarkshire, Scotland, which also has a high rate of lung cancer and bird keeping.

\section{Subjects and methods}

Patients with lung cancer (ICD 162) were individually matched with two controls, one admitted to hospital with heart disease (ICD 410-414) and the other with an orthopaedic condition. We used two controls to eliminate the possibility of bias that might arise if the control disease was also associated with bird keeping. The intention was to match for sex, age at admission (within five years), date of admission (within six months), and admission status or place of interview. A case and matched controls were all either currently admitted (June 1990 to February 1992) and interviewed in Monklands District General Hospital or admitted in the past two years (mainly during September 1988 to July 1989) and interviewed at home. Exceptionally, when a patient with lung cancer was interviewed in hospital and no matching control was available in hospital after some months, an otherwise suitable recently discharged patient was interviewed at home and used as the control. All patients came from the same catchment area, Monklands district (population 220000 ). The intention was to study about three times the number of lung cancer cases considered by Holst to allow a more precise estimation of risks associated with bird keeping.

Interviews were conducted with the subject, if available, or with the next of kin by one of three interviewers. For every period of at least a year when the subject lived where domestic birds were kept data were collected on the subject's age, the types and numbers of birds kept, and where they were kept. Questions were asked about whether the patient had ever (and if so in the 15 years before admission) worked on a poultry farm, worked in greenhouse horticulture with chicken manure, regularly cleaned bird cages, or frequently visited friends, neighbours, or family members who owned birds. Questions were also asked about dogs, cats, or other domestic pets; smoking; occupation; alcohol consumption; diet; history of respiratory diseases; and demographic variables. The histological type of lung cancer was recorded when available. Indices were derived for social group, units of alcohol drunk, and daily intake of retinol and $\beta$ carotene.

Statistical techniques used included standard unmatched stratified and unstratified contigency tables and matched conditional logistic regression analysis. ${ }^{3}$ For both the unmatched and matched methods, the relative risk of lung cancer associated with exposure to bird keeping or other variables was estimated by the odds ratio together with its $95 \%$ confidence interval. Probability values given are two tailed.

\section{Results}

We interviewed 452 subjects. Ten subjects were rejected (questionnaire inadequately completed, provisional diagnosis of lung cancer incorrect, same person reinterviewed in error). To try to minimise loss of information from patients matched with the controls whose interviews were rejected we reallocated such patients into new matched sets. In the end 143 triads (one case, one control of each type) were formed, keeping to the initial matching criteria as far as possible. All triads were matched for sex (104 men, 39 women), and age (except for one triad in which the orthopaedic control was seven years older than the case), and all but nine controls had been admitted within six months of the case. In all, 111 triads were matched for place of interview (56 at home, 55 in hospital). We defined the 106 triads matched for all four of the original criteria as good quality and the 37 matched for fewer as bad quality.

Diagnosis of lung cancer was histologically confirmed in 127 of the 143 cases ( $89 \%$ ), the other 16 cases all showing convincing clinical evidence. The source of the specimen was resection or necropsy in 29 cases, biopsy in 86 , and aspiration in 12 , and the distribution of histological type was squamous cell 66 , small cell 29 , adenocarcinoma 12 , large cell 16 , and other or unspecified 4 . The mean age of the cases $(65.4$ years) was slightly older than that of the heart disease controls $(65 \cdot 0, p=0.049)$ and orthopaedic controls (64.9, $p=0.012)$. More cases (53/143) than controls $(44 / 286$; $\mathrm{p}<0.001)$ had died by the time of interview and so had information supplied by a spouse or other next of kin. Seventy one cases $(50 \%)$ compared with 19 controls (7\%) were interviewed by AJSG. The remainder were interviewed by medical secretaries.

A higher proportion of cases than controls had ever smoked (97\% (138) v 78\% (223); $\mathrm{p}<0.001)$ or were current smokers at the time of admission $(68 \%$ (97) $v$ $40 \%(115) ; \mathrm{p}<0.001)$. Because smoking was associated with several other risk factors (occupational exposure to dust or fumes, alcohol consumption, eating fried food, reduced consumption of fruit and green vegetables) we decided generally to adjust for smoking status in subsequent analyses. For certain questionsparticularly on diet and to some extent on bird keeping-systematic differences between responses for the different interviewers emerged, so we also adjusted for interviewer. Because adjustment for respondent had little effect in analysis once interviewer and smoking had been adjusted for, analyses were not adjusted additionally for respondent.

Statistical analysis to test for effects of bird keeping was conducted in two stages. The first stage used standard stratified $\chi^{2}$ techniques to adjust for smoking and interviewer, unmatched methods being used to avoid loss of power. In the second stage matched conditional logistic regression analyses were used. The latter technique has the advantage of taking the matching explicitly into account, but the model assumptions are difficult to verify. Conclusions reached by both techniques were comparable.

Table I compares the exposure to birds in cases and the combined controls. No signficant differences were found for living in a household where birds were kept at any time, at various specific times, 5-14 years before admission (the index used by Holst), or in childhood. Nor was there any difference for keeping 10 or more birds. Odds ratios for lung cancer were raised in cases living in households keeping birds in the 20 years before admission. Lung cancer was not related to keeping birds in the house (rather than a shed, conservatory, pigeon loft, or aviary) or to keeping budgerigars, canaries, finches, or members of the parrot family. There was, however, a significantly increased risk associated with keeping pigeons (odds ratio $3 \cdot 53,95 \%$ confidence interval 1.56 to $7 \cdot 98$ ). Other bird related variables were not different between cases and controls except for working in greenhouse horticulture with chicken manure, although the odds ratio $(20 \cdot 0)$ had a wide confidence interval (3.35 to 119$)$ as so few subjects had done this work.

For the more common responses Table I also gives odds ratios for comparison of cases with each control group. Generally results were similar and additional analysis (results not shown) showed that there was no significant difference between the two control groups for any of the indices of bird keeping. The increased odds ratio in relation to pigeon keeping was seen with both heart disease controls $(2 \cdot 77,95 \%$ confidence 


\begin{tabular}{|c|c|c|c|c|c|c|c|c|c|}
\hline \multirow[b]{2}{*}{ Index of exposure } & \multicolumn{3}{|c|}{ No of people exposed ${ }^{\star}$} & \multicolumn{2}{|c|}{ Cases $v$ combined controls } & \multicolumn{2}{|c|}{ Cases $v$ heart disease controls } & \multicolumn{2}{|c|}{ Cases $v$ orthopaedic controls } \\
\hline & $\begin{array}{c}\text { Lung cancer } \\
\text { cases } \\
(n=143)\end{array}$ & $\begin{array}{l}\text { Heart disease } \\
\text { controls } \\
(n=143)\end{array}$ & $\begin{array}{l}\text { Orthopaedic } \\
\text { controls } \\
(n=143)\end{array}$ & $\begin{array}{c}\text { Odds ratio for lung } \\
\text { cancer } \\
\text { (95\% confidence interval) }\end{array}$ & p Value & $\begin{array}{c}\text { Odds ratio for lung } \\
\text { cancer } \\
\text { (95\% confidence interval) }\end{array}$ & & $\begin{array}{c}\text { Odds ratio for lung } \\
\text { cancer } \\
(95 \% \text { confidence interval })\end{array}$ & $\mathrm{p}$ Value \\
\hline \multicolumn{10}{|l|}{ Any bird kept in household: } \\
\hline Ever & 72 & 76 & 71 & $1.29(0.79$ to 2.12$)$ & & $1.27(0.71$ to 2.28$)$ & & $1.36(0.77$ to 2.41$)$ & \\
\hline 5-14 Years before admission & 21 & 26 & 18 & $1.58(0.82$ to 3.05$)$ & & $1.25(0.58$ to 2.70$)$ & & $2.05(0.95$ to 4.40$)$ & $0 \cdot 10$ \\
\hline 5 Years before admission & 8 & 15 & 11 & $0.90(0.32$ to 2.58$)$ & & $0.57(0.19$ to 1.73$)$ & & $1.47(0.41$ to 5.27$)$ & \\
\hline 10 Years before admission & 13 & 14 & 11 & $1.66(0.73$ to 3.77$)$ & & $1.19(0.48$ to 2.99$)$ & & $2.89(0.97$ to 8.61$)$ & $0 \cdot 11$ \\
\hline 15 Years before admission & 14 & 16 & 11 & $1.86(0.89$ to 3.92$)$ & $0 \cdot 15$ & $1.63(0.66$ to 4.04$)$ & & $2.22(0.92$ to 5.31$)$ & $0 \cdot 12$ \\
\hline 20 Years before admission & 18 & 15 & 13 & $2.21(1.05$ to 4.65$)$ & 0.06 & $2.21(0.89$ to 5.48$)$ & $0 \cdot 13$ & $2.01(0.83$ to 4.87$)$ & 0.19 \\
\hline 30 Years before admission & 18 & 27 & 20 & $0.99(0.51$ to 1.92$)$ & & $0.90(0.42$ to 1.95$)$ & & $1.16(0.54$ to 2.46$)$ & \\
\hline 40 Years before admission & 14 & 17 & 8 & $1.18(0.53$ to 2.66$)$ & & $1.01(0.39$ to 2.62$)$ & & $1.76(0.65$ to 4.75$)$ & \\
\hline Up to age 15 & 22 & 15 & 16 & $0.88(0.42$ to 1.85$)$ & & $1.07(0.43$ to 2.67$)$ & & $0.77(0.32$ to 1.87$)$ & \\
\hline Ever in house & 59 & 65 & 64 & $1.09(0.67$ to 1.79$)$ & & $1.09(0.61$ to 1.96$)$ & & $1.10(0.62$ to 1.95$)$ & \\
\hline \multicolumn{10}{|l|}{ Type of bird kept: } \\
\hline Budgerigar & 53 & 59 & 55 & $1.14(0.68$ to 1.90$)$ & & $1.06(0.58$ to 1.94$)$ & & $1.17(0.65$ to 2.09$)$ & \\
\hline Canary & 7 & 17 & 16 & $0.54(0.21$ to 1.40$)$ & & $0.62(0.21$ to 1.86$)$ & & $0.51(0.18$ to 1.45$)$ & \\
\hline Pigeon & 19 & 10 & 7 & $3.53(1.56$ to 7.98$)$ & 0.005 & $2.77(1.09$ to 7.05$)$ & 0.06 & $5.79(1.85$ to 18.2$)$ & 0.005 \\
\hline Finch & 2 & 2 & 2 & $1.28(0.23$ to 7.18$)$ & & & & & \\
\hline Cockateel, parakeet, lovebird, or parrot & 5 & 5 & 3 & $2.03(0.59$ to 7.04$)$ & & & & & \\
\hline \multicolumn{10}{|l|}{$\geqslant 10$ Birds kept in household } \\
\hline 5 Years before admission & 3 & 4 & 2 & $1.74(9.37$ to 8.16$)$ & & & & & \\
\hline 10 Years before admission & 6 & 4 & 5 & $1.77(0.65$ to 4.84$)$ & & & & & \\
\hline 15 Years before admission & 4 & 5 & 5 & $1.41(0.50$ to 4.02$)$ & & & & & \\
\hline 20 Years before admission & 4 & 6 & 5 & $1.22(0.41$ to 3.59$)$ & & & & & \\
\hline 30 Years before admission & 5 & 8 & 4 & $0.84(0.27$ to 2.65$)$ & & & & & \\
\hline 40 Years before admission & 7 & 7 & 4 & $1.44(0.53$ to 3.95$)$ & & & & & \\
\hline \multicolumn{10}{|l|}{ Ever worked: } \\
\hline In pet store or as keeper of cage birds & 5 & 9 & 3 & $2.22(0.73$ to 6.72$)$ & & & & & \\
\hline On poultry farm & 4 & 3 & 3 & $1.63(0.51$ to 5.19$)$ & & & & & \\
\hline In greenhouses with chicken manure & 4 & 2 & 1 & $20.01(3.35$ to 119$)$ & 0.006 & & & & \\
\hline Ever regularly cleaned bird cages & 32 & 36 & 27 & $1.21(0.69$ to 2.13$)$ & & $1.00(0.53$ to 1.88$)$ & & $1.64(0.82$ to 3.29$)$ & \\
\hline Ever frequently visited bird owners & 26 & 26 & 19 & $0.99(0.51$ to 1.92$)$ & & $0.78(0.37$ to 1.63$)$ & & $1.33(0.58$ to 3.02$)$ & \\
\hline
\end{tabular}

* $=$ In bedroom, living room, kitchen, or other room in house rather than in shed, conservatory, pigeon loft, or outdoor aviary.

For rarer exposures odds ratios and confidence intervals not shown for second and third comparisons because of insufficient data.

TABLE II-Relation of lung cancer to ever having lived where pigeons were kept

\begin{tabular}{|c|c|c|c|}
\hline & $\begin{array}{l}\text { No }(\%) \text { of } \\
\text { lung cancer } \\
\text { cases }\end{array}$ & $\begin{array}{l}\text { No }(\%) \text { of } \\
\text { combined } \\
\text { controls }\end{array}$ & $\begin{array}{c}\text { Odds ratio } \\
\text { ( } 95 \% \text { confidence interval) }\end{array}$ \\
\hline Overall & $19 / 143(13)$ & $17 / 286(59)$ & $2 \cdot 42(1.24$ to $4 \cdot 75)$ \\
\hline \multicolumn{4}{|l|}{ Sex: } \\
\hline Male & $16 / 104(15)$ & $13 / 208(6)$ & $2.73(1.29$ to 5.78$)$ \\
\hline Female & $3 / 39(8)$ & $4 / 78 \quad(5)$ & $1.54(0.33$ to 7.23$)$ \\
\hline \multicolumn{4}{|l|}{ Age (years): } \\
\hline $39-54$ & $1 / 11 \quad(9)$ & $2 / 26(8)$ & $1.20(0.09$ to 15.3$)$ \\
\hline $55-64$ & $7 / 51 \quad(14)$ & $3 / 109(28)$ & $5.62(1.58$ to 20.0$)$ \\
\hline $65-74$ & $7 / 60(12)$ & $10 / 118(85)$ & $1.43(0.51$ to 3.95$)$ \\
\hline $75-93$ & $4 / 21 \quad(19)$ & $2 / 33$ (6) & $3.65(0.65$ to 20.55$)$ \\
\hline \multicolumn{4}{|l|}{ Triad quality: } \\
\hline Good & $11 / 106(10)$ & $13 / 212(6)$ & $1.77(0.77$ to 4.07$)$ \\
\hline $\mathrm{Bad}$ & $8 / 37 \quad(22)$ & $4 / 74 \quad(5)$ & $4.83(1.46$ to 16.0$)$ \\
\hline \multicolumn{4}{|l|}{ Interviewer: } \\
\hline $\mathrm{AB}$ & $4 / 39(10)$ & $4 / 146(27)$ & $4.06(1.06$ to 15.5$)$ \\
\hline jw & $7 / 32(22)$ & $12 / 120(10)$ & $2.52(0.92$ to 6.90$)$ \\
\hline AJSG & $8 / 71$ (11) & $1 / 19(5)$ & $2.29(0.28$ to 18.7$)$ \\
\hline \multicolumn{4}{|l|}{ Respondent: } \\
\hline Subject & $12 / 90 \quad(13)$ & $14 / 233(6)$ & $2.41(1.09$ to 5.33$)$ \\
\hline Spouse & $5 / 31 \quad(16)$ & $1 / 27$ & $5.00(0.64$ to 39.0$)$ \\
\hline Other & $2 / 22$ (1) & $2 / 26(8)$ & $1 \cdot 20(0.15$ to $9 \cdot 48)$ \\
\hline \multicolumn{4}{|l|}{ Histological type of lung cancer: } \\
\hline Squamous or small cell & $11 / 94 \quad(12)$ & $15 / 188(8)$ & $1.53(0.67$ to 3.46$)$ \\
\hline Adenocarcinoma or large cell & $5 / 28(18)$ & $1 / 56(12)$ & $11.96(1.95$ to 73.4$)$ \\
\hline \multicolumn{4}{|l|}{ Smoking habits: } \\
\hline Never or former smoker & $7 / 46 \quad(15)$ & $11 / 171(6)$ & $2.61(0.98$ to 6.98$)$ \\
\hline Current smoker & $12 / 97(12)$ & $6 / 115(5)$ & $2.56(0.95$ to 6.93$)$ \\
\hline Current manufactured cigarette smoker of $\geqslant 20 /$ day & $9 / 45(20)$ & $4 / 50(8)$ & $2.88(0.84$ to $9 \cdot 78)$ \\
\hline
\end{tabular}

interval 1.09 to $7 \cdot 05)$ and orthopaedic controls $(5 \cdot 79$, $1 \cdot 85$ to $18 \cdot 2$ ). Further analysis (table II) showed the increased risk associated with keeping a pigeon was evident in subgroups of the population by sex, age, triad quality, interviewer, respondent, smoking habits, and histological type of lung cancer. Only for histological type, where the relation was much stronger for adenocarcinoma and large cell cancer than for squamous or small cell cancer, did the difference in odds ratios between the subgroups approach significance. All subjects who reported keeping pigeons stated that they kept them outside the house in a pigeon loft, shed, or outdoor aviary. With two exceptions 10 or more pigeons were kept at any one time.

After adjustment for smoking and interviewer, no clear or consistent relations were seen between lung cancer and the keeping of dogs, cats, and other pets for any period. Odds ratios for keeping pets at any time were $1.07(0.61$ to 1.87$)$ for dogs, $0.77(0.4$ to 1.30$)$ for cats, and $1.22(0.63$ to 2.37$)$ for other pets.

Various matched conditional logistic regression analyses were conducted. In the final model all the variables included were significant at least at the $90 \%$ confidence level (table III). After taking account in the model of smoking, alcohol consumption, margarine consumption, dietary $\beta$ carotene, and also interviewer and respondent the odds ratio associated with ever having kept a pigeon was estimated to be 3.90 (1.20 to $12.62)$. No other variable, when included in the model, significantly improved the fit. Working in greenhouse horticulture with chicken manure was no longer significant, partly because it was partially correlated with keeping a pigeon.

\section{Discussion}

Holst found that, after adjustment for smoking and vitamin $\mathrm{C}$ intake, risk of lung cancer was 6.7 times higher (95\% confidence interval $2 \cdot 2$ to 20 ) in people who had kept caged birds in the home for longer than six consecutive months in the five to 14 years before diagnosis. ${ }^{2}$ In this period the frequency of bird keeping was higher in the cases, whether attention was restricted to budgerigars and parrots, canaries, or pigeons or to different types of lung cancer. We found no evidence of such a strong relation. For the period five to 14 years before diagnosis, the odds ratio for bird keeping was positive $(1.58)$ but the $95 \%$ confidence interval of 0.82 to 3.05 was inconsistent with a relative

TABLE III-Results of matched conditional logistic regression analysis

\begin{tabular}{lcc}
\hline Variable & $\begin{array}{c}\text { Odds ratio for lung cancer } \\
\text { (95\% confidence interval) }\end{array}$ & p Value \\
\hline Current smoker $(v$ never smoked & $19.69(4.27$ to 90.76$)$ & $<0.001$ \\
Former smoker $(v$ never smoked) & $16.42(3.40$ to 79.37$)$ & $<0.001$ \\
Alcohol ( $\geqslant 3$ units per week) & $3.67(1.44$ to 9.38$)$ & 0.005 \\
Margarine consumption (ever) & $0.49(0.26$ to 0.91$)$ & 0.02 \\
$\beta$ carotene $(\geqslant 2000 \mu \mathrm{g} /$ week $)$ & $0.56(0.30$ to 1.05$)$ & 0.07 \\
Pigeon (ever) & $3.90(1.20$ to 12.62$)$ & 0.02 \\
\hline
\end{tabular}

*The model also included terms for interviewer and respondent (subject/other). Questions on diet and alcohol consumption related to the five years before admission. 
risk as high as $6 \cdot 7$. Nor was there any significant relation with keeping birds at other times, keeping large numbers of birds at any time, or keeping budgerigars, canaries, finches, or parrots. However, a significant relation with keeping pigeons at any time was noted (odds ratio $3.90,1.20$ to 12.60 ), which was consistently seen in various subsets of the data and was not explained by confounding.

Differences between our findings and Holst's could not be explained by Holst restricting attention to subjects aged less than 65 , since restricting analysis to this age group in our study did not change our findings (ever kept birds, odds ratio $1.03(0.69$ to 1.53$)$; kept birds $5-14$ years before admission, $1.05 \quad(0.53$ to $2 \cdot 08)$; ever kept pigeons, $3.45(1.14$ to $10 \cdot 65)$ ). Holst used general practice controls whereas we used hospital controls, but the similarity of results for our two control groups suggests that this has not significantly affected our results. We do not believe that adjustment for different confounding variables could explain the discrepant results. Though in both studies such adjustment had some effect, the effect was much smaller than the difference in findings between the studies. Holst used a self administered questionnaire, whereas we used interviewers. Though this might have affected data quality it seems unlikely it could explain our differing results. Of more concern is the fact that in our study, for practical reasons, one of the interviewers (AJSG) interviewed most of the cases in his unit and controls were interviewed by medical secretaries; perhaps partly because subjects react differently to being interviewed by medical secretaries than by a consultant responses varied by interviewer. However, since interviewer was taken account of in the analysis bias should not have occurred.

PATTERNS OF BIRD KEEPING

Comparison of our results with those of Holst showed that in Scotland the proportion of budgerigars was much higher than in the Netherlands. However, the four main types of birds kept were the same and it seems unlikely that this could explain the differences in our results. Differences between the countries where birds are kept and how hygienically they were kept may have contributed to differences. We have no direct comparative data but Holst refers to birds being kept in the bedroom-reported by only two subjects in our study - and discusses the possibility that the increased risk may be reduced by better hygiene. ${ }^{2}$ The fact that buildings in the Netherlands tend to be more draught proof with a lower intake of fresh air than in Scotland might help to explain the difference, although levels of particulates in bird keepers' homes have not been compared in the two countries. Nevertheless, in our study increased risk was noted only for pigeon keeping and pigeons were always kept outside the house.

\section{TRUE RISK}

The possibility that chance contributed to the dif ference between the results of the two studies deserves comment. Although the confidence limits for bird keeping 5-14 years before interview in Holst's study $(2 \cdot 20$ to $20 \cdot 1)$ and our study $(0.82$ to 3.05$)$ are significantly different, which at first seems to argue against chance, Holst notes the relative risk was considerably less for other periods. It may be that any true effect is more modest, having been overestimated by Holst and perhaps underestimated in our study. Further studies are needed to resolve this. Such studies would also guard against the relation we found with pigeon keeping having arisen by chance because of the large number of case-control comparisons conducted.

We could not confirm the large increased risk of lung cancer for bird keeping reported by Holst. However, we did find a significant association with pigeon keeping, and it remains possible that bird keeping confers some risk of lung cancer. Further research is needed to clarify this issue.

We thank the consultants in the medical and orthopaedic unit of Monklands Hospital for their cooperation, Mrs A M Brown and Mrs J M Wilson for help with the interviewing, Mrs E K Marlow for data processing, Dr S Darby and Mrs I Roe for permission to use their dietary questionnaire and advice on creation of indices for daily retinol $\beta$ carotene intake, Mrs G Brown for coding social grade, and Mrs P Wassell for typing this report. 1 Holst PAJ, Kromhout D, Brand R. Pet birds as an independent risk for lung
cancer. BMF 1988;297:1319-21.

2 Holst PAJ. Bird keeping as a source of lung cancer and other human diseases. A need for higher hygienic standards. Heidelberg: Springer-Verlag, 1988.

3 Breslow NE, Day NE. Statistical methods in cancer research. Vol 1. The analvis of case-control studies. Lyons: International Agency for Research on Cancer, 1980

(Accepted 21 September 1992)

\section{ONE HUNDRED YEARS AGO}

\section{FILTERS FOR COTTAGERS}

It has been suggested that cottagers might be induced to make filters for themselves out of flower-pots, "polarite," and sand, in order to guard against poisoning by impure water. The immediate cause of this suggestion, in its present form, seems to have been an inquest upon a child whose death was shown to have been due to the impurity of the water supply at the cottage where it lived. According to a contemporary the county analyst for Cheshire, Mr. Bell, in commenting on the case, stated tha he could not see why every cottager should not have a flower-pot filter at his door, since the total cost would be but a few pence, magnetic oxide of iron or "polarite" being purchaseable at about one penny per pound; he is reported to have added that he had made some experiments which went to show that the purifying power of a mixture of sand and "polarite" was very satisfactory. Whatever may be the virtues of this substance, and however useful the suggestion, the great difficulty is to get the ordinary cottager to purchase the former, and to carry out the latter. Anyone having even a superficial acquaintance with cottagers will probably admit that, as a rule, they can hardly be depended upon to take the trouble to make an apparatus even so simple as the one suggested for any such purpose as the one in view, nor to take the trouble to use it if it were made for them. The flower-pot filter is no new thing. A description of it is to be found in the Family Friend for the year 1850, the materials used being sand and charcoal, and the objections which could be brought against these apply equally to the mixture now recommended. The great difficulty in the way of domestic filtration of water is the uncertainty which attaches to the time during which the filtering materials will act efficiently; this depends, of course, on a variety of circumstances, such as the nature and condition of the materials, the closeness of the packing, the degree of pollution of the water, the rate of filtration, and so forth. Some good may doubtless be done by endeavouring to get such a suggestion carried out, but to try to counteract the evil of polluted water in villages by a flower-pot filter scheme is to begin at the wrong end, and may amount to a misapplication of energy. Nevertheless, we freely admit that, as a temporary expedient, it may be recommended.

(BMF 1892;ii;:477) 